\title{
The Medical Value of Traditional Chinese Garden Art
}

\author{
Xian Zhou \\ Department of Art, School of Art and Design, Hubei University of Technology, Wuhan Hubei, 430068, China
}

Keywords: Taoist medicine, Health, Traditional, Psychological, City, Natural

\begin{abstract}
As the Chinese proverb goes: "there are the same origins between medicine and Taoism”, which means that the origin of Chinese medicine and Taoism is the same. So what is the same origin? It is a simple world view of ancient China: the unity of heaven and man. Specifically, in the theory of Chinese medicine, this view is the correspondence of human body and natural environment. This paper summarizes the Taoist medicine from the perspective of Traditional Chinese Medicine (TCM) history. Then, from the perspective of garden history, the paper clarifies that the form of landscape art in Chinese traditional garden is derived from the Xianju archetype in Taoism. For example, the evolution among the folk customs of "begging the gods" in the wild during the Qin and Han dynasties, the "wandering fairy" in the Wei and Jin dynasties, and the customs of the "garden activities" in the city after the Song dynasty. The relationship between urban landscape and Taoist medicine can be seen from this evolution. Therefore, from the perspective of history, the first utility of Chinese traditional garden is the treatment of the heart, and the second is artistic aesthetics.
\end{abstract}

\section{Introduction}

This is the innovative viewpoint proposed in this article. However, art and the treatment of the heart are not contradictory, because art itself is a natural therapy in western modern clinical psychology. Next, the article elaborates the medical value of garden art, especially the psychological medicine value, from the material and mental aspects. Finally, the article sums up the role of natural garden in promoting the mental health of modern people.

\section{The Refection of the View of "the Unity of Heaven and Man" in Taoism Medicine and the Gardens.}

In the history of science and technology in China, Joseph Li put forward that "Taoism is the only mysterious system that is not opposed to science in nature... Taoism has a concept of immortality from the beginning. There is no such example in the rest of the world, and the idea of immortality is of great importance to science”. Throughout the history of science in the world, all kinds of sciences have experienced the process from fantasy to exploration, experiment and application. For example, human fantasy to the moon, and then explore the aerospace science and technology, through repeated experiments, finally the spacecraft successfully lands on the moon. The biggest difference between Taoism and other religions of the world lies in that Taoism doesn't form the structure of the unreal world, but face to the real life in the real world directly. While Christian has "paradise", Muslim has "the kingdom", and Buddhists have "heaven", etc. Therefore, the Taoists persevere in their dream of "living the life as long as the heaven and earth". Although it has not been realized today, the illusion of long live gives the believers the courage to explore the relationship between human body and the heaven and earth, and finally promotes the birth and development of traditional Chinese medical science. In order to better understand the discussion below, the theory of Chinese medicine history, which is the most obvious and easiest part to understand among the excellent Chinese medicine theory, and also derived from the "unity of heaven and man" from Taoism, is referred to as Taoism medicine. 


\section{The "Correspondence of Human Body and Natural Environment" in Taoism medicine}

Western medicine focuses on the scientific research on microorganism, virus, bacteria and even molecular structure. The pathogenic mechanism of micro-organisms, such as bacteria, has not been clarified until the science of epidemic febrile disease was established in the Qing dynasty. In contrast, traditional Chinese medicine is a scientific study of climate, environment, pathogenic substances and human diseases in a macroscopic view of the relationship between man and heaven. The Internal Classic defines the relationship between man and nature as "Man comes to life through the Qi of heaven and earth, and matures in accordance with the laws of the four seasons", which means that man is born in nature and should observe the natural law of seasons. From the perspective of modern science, there are three elements in this objective world. Materials, energy and information. In terms of materials, Taoist medicine holds the nature as metal, wood, earth, water, fire. And according to the characteristics of these five elements, it makes the viscera of human body correspond to five characteristics (For example, earth has the characteristics of the acceptance of everything, and the spleen has the function of transport blood, so spleen belongs to earth). The mutual promotion and counteraction rules of five elements can be used to illustrate the connection between the five viscera and the mechanism of the movements of Qi and blood, also known as the rule of human energy circulation. Meanwhile, if there is something wrong with the five viscera, the information transfer regularity of the disease can be observed through the abnormal change of physique meridian. To put it simply, the concept of the five elements of Taoist medicine firstly make the "nature" corresponded to human's viscera state from the perspective of matter.

It is believed that "the reasons why there are diseases in the world are the wind, cold, heat, wetness, dryness and fire". And the wind, cold, heat, wetness, dryness and fire, also known as "six qi", are only the different climate phenomenon in nature. According to Taoist medicine, the abnormal phenomenon of "six qi" is the primary factors of the cause of exogenous contraction for human body, which also shows the mutual interaction between the weather and human body. The modern medicine has also proved that the effects of drugs are indeed associated with seasonal climates, such as the increase in toxicity if the digitalis are taken under the low pressure and storms, etc.

In conclude, Taoist medicine is a macroscopic medicine, which is based on the "correspondence between human and nature”.

\section{The Landscape Pattern of Chinese Gardens Origins from the Taoist Immortal View}

Taoism, medicine and landscape art are originated from Lao Zi and Zhuang Zi philosophy. Zhuangzi's thoughts in particular have more influence on the art field. Zhuangzi thinks that nature is the most beautiful, and people should observe law of naturalness and cherish truth, also known as "original heaven and earth beauty of things in science". There are a lot of Chinese scholars who write landscape poetry and draw landscape paintings for the beauty of nature. And the number of the poetry and paintings perhaps is the largest in the world.Zhuangzi described that "there is a god who lives in the Gushe mountain", which pulls the god of heaven down to the mountain in the real world. Afterwards, Liezi expanded what Zhuangzi said, "Gushe Mountains lie in among the sea", which showed the spatial pattern of Xianju with water and mountains. By the time of the Qin and Han dynasties, there was a popular culture of "pray for the gods"among emperors and the folks. The necromancer defined the mountains "among the sea" specifically as the three mountain islands in the East China Sea, Penglai, Fangzhang and Yingzhou. However, no one can find it, whether the Gushe mountain or Penglai. Until the end of the East Han dynasty, Taoism was established. The "cave paradise" in Taoist doctrine described the living places of the god men in details, and defined them by grade as the mountains on earth, which shortens the distance between people and the god men greatly. Therefore, "fairy traveling" replaced the searching help from god man, which was originated from those scholars. There were a lot of people who believed in Taoism in Jin dynasty, "The scholar of knowledge and the children of the famous ethnic group were also happy to believe Taoism", page 73. For example, Xie lingyun invented the hiking shoes for the convenient fairy traveling, which was 
known as "Xiegong Ji", and he believed the Taoist medicine of "always believe those methods of how to be god men, and will live a better life in the whole lifetime" and "Looking for rare drugs among all famous mountains, get across all rivers and then rest the horses ". Tao hongjing was even more devoted to walking through famous mountains and searching for fairy drugs. In "the book of appreciation", he directly referred to the landscape on earth (the world of desire) as the immortal. He lived in the mountain as a poet, a doctor, and a religious man. In a word, the activity of fairy traveling is not only the aesthetic practice of landscape art, but also has the utilitarian color of Taoist medicine. The fairy traveling fashion of literati continued to later generations, such as Libai in Tang dynasty "having the fairy traveling at 15 years old, and never have a rest for it", or "having the fairy traveling around five famous mountains even they are far between, and be fond of traveling among mountains”, which means that the fairy traveling is traveling among mountains. Therefore, most of the private gardens in Song dynasty were located in the mountains and forests, and named after a mountain villa, a mountain pavilion, a mountain, a water pavilion, or a water hut, etc.

People's passions for mountains and rivers has changed in Song dynasty. Those famous gardens in Song dynasty were in the cities, as described in Li Gefei's "Famous gardens in Luoyang”. Since the function of the city in Song dynasty has changed, and the function of commerce, recreation and entertainment became more and more obvious. The neighborhood system in the city was completely abandoned, and the streets became truly open business street. Restaurants as a symbol of urban prosperity "are in the street, and among the open overlapping tall buildings" [2] on page 180, and you can look down the palace from those even taller ones. Did this buildings dare to appear before Song dynasty? In addition, many restaurants in Doingjing were famous for their garden-oriented environment and were named after "garden", such as Zhangzhai garden restaurant, Guo Xiaoqi garden restaurant, Zhongshan garden restaurant, etc. What valuable is that these private gardens were generally open to the public at regular intervals. The whole country was follow the "garden" fashion. In Song dynasty, not only the royal nobility but also the ordinary citizens enjoyed wandering gardens. Compared with the fairy traveling among mountains, the utilitarian the pursuit of Taoism from wandering gardens was less, while the aims to strengthen the body was highlight. For example, the emperor Zhenzong opened the west pool to let people enjoy the "competition for bid", which was continued to South Song dynasty with a more abundant form--water play activities into the more open west lake. And the emperor Huizong, he "strongly advocated the association between political, economic, cultural life and the 'five yun and six qi', which actually promoted the 'movement'”, page 105. Also as seen from the poem "Cuju in famous gardens are called spring outing”, gardens in spring were the best places for football. As the Internal Classic described "the ancients lived between the beasts, move to escape the cold, and stay to avoid the summer", which means that the ancient human lived in wilderness that beasts always hang out, so they needed to escape the cold in the form of movement, and it better illustrates the importance of sports for health.

\section{The Relationship Between Traditional Garden and Taoist Medicine}

\subsection{The Media Substances of Garden and the Physical Heath}

All the media substances, like landscapes, wind, moon, etc are related to health. The first is landscape. The limitation of private garden space determines that the nature and mountains can only be replaced by the freehand brushwork stone scoop of water in traditional Chinese painting.

So scholars of later generations in their family gardens could seldom feel the "true feelings" of "mountains are great during sunrise and sunset". Furthermore, for getting close to the feeling, although "real mountains" were not available, the "mountain forests" were easy to get close to.

Therefore, in the gardens of scholars in Song dynasty "there were the forest landscapes with large trees, such as bamboo forest, merlin, peach forest, pine Berlin, etc. In contrast, the mountain pool and the landscape of architecture were only as the accessories.” [4], page 223, which were suitable for leisure. From the perspective of health, mountain forests can not only shade in summer, but also purify the air, especially Berlin, such as "one hectare of Berlin can produce 30 kilograms of 
sterilization in 24 hours" [5] page 95. But the function of garden pool is not only for aesthetic entertainment, but also the most important thing is production, such as "raising deer and fish" [7], page 51, etc. If the water is poisoning, toxins spread through the food chain of the wetland plant, mollusks, fish, and human body, then "human" body gets the greatest harm. Please refer to the "Silent Spring” by Rachel Carson, and there will be no more discussion about it.

\subsection{Garden Art and Mental Health}

German aesthetes Hess Anfield held that landscape is the art to enhance the natural beauty, and it "should inspire all the emotion of the viewer" [11] on page 267, which shows that the natural landscape and people emotional areas are linked. "Not Confucianism but Taoism, not Taoism but Confucianism" is the Chinese traditional psychological paradigm. If quit for the officials, the heart of those politicians would be hidden among the gardens with lakes and mountains, and the natural style gardens are the spiritual healing space for them. But how can this limited space fit the infinite mountain gulls? So the garden borrows directly from the landscape painting experience; However, the painters who delve into the landscape painting "all make every effort to 'search for the weird mountains for thier drafts'” and get the those great results [12] page 133. It can be seen that the theoretical achievements in Song dynasty that the landscape paintings were derived from the accumulated experience of the ancient poets and painters. Therefore, the garden wandering as a social custom's replacement of the fairy traveling has the historical possibility. Moreover, the gardens also become the fairy place for garden owners to escape from the shackles instead of staying in the true landscapes.

\subsubsection{Scenery Art and Mental Health}

Carefree and happy, it is to say that the mind is relaxed and then the spirit is comfortable. Taoist medicine believes that "if the heart moves, the the viscera begin to shake", which means that those sad emotions will cause psychological disease, and do harm to the viscera. While the classic example of using scenery to heal the disease must be the person from $\mathrm{Wu}$ who gave the prince in Chu the mental instructions described in "Qifa” by Meicheng. The method of this person from Wu was to guide the prince to fantasy by speech.

\subsubsection{Aojing Art and Mental Health}

As we can see from "outside the handrails in Pingshantang is the blue sky, and the mountains are hard to see clearly" in "Chaozhongchuo" by Ou yangxiu, the location of Pingshantang was at the commanding heights and took the sky as the background, which shows that there was a narrow river space on the ground at the foot of the mountains before arrived in Pingshangtang. How to make this ground space be far and deep? It made the path meander along the coast and makes twists and turns, and the plants such as bamboo trees along the way formed the curtain effect of the hidden line of sight, resulting in a long sense of "deeper and deeper" space. Whether the lowlands were deep or the heights were wide open, they were designed to stimulate the deep extension of the vision and to get the comfortable feeling.

\section{Conclusions}

From ancient times to the present, diseases are the common life problems faced by all mankind. Especially in the big cities, the fierce competition, the traffic noise, the environment pollution, the existence pressure etc., are make the mental illness very outstanding. "Although studies have shown that plants and nature can help people recover. These results show that our visual environment has a profound effect on our physical and mental health. [16] Page 46. However, the reality is that the cities we live in are de-naturalizing. No matter in the United States or China we should learn from the Nordic countries' experience in the green city movement. 


\section{References}

[1] Fu Qinjia. History of Chinese Taoism, Beijing: United Press, 2005: 73.

[2] Yi-Wen Yi. Walk in the city of Song Dynasty, Beijing: Zhonghua Book Company, 2005: 180 Cited from (Japanese) Kato, Song urban development.

[3] (Germany) Hegel, translated by Zhu Guangqian. Aesthetics, (Volume II). Beijing: Commercial Press, 1979: 24.

[4] Zhou Weiquan. History of Chinese Classical Gardens, Beijing: Tsinghua University Press, 1999: 223.

[5] Chen Youmin editor in chief of garden trees, Beijing: China Forestry Publishing House, 2000: 95.

[6] Li Shuhua. Horticultural therapy science research progress, Chinese Garden, 2009 (07).

[7] (Ming) counted Cheng, Chen Zhi. Park Note, (Park said articles.) Beijing: China Building Industry Press, 1988: 51.

[8] Zhang Junhua. Gardening therapy, Chinese Garden, 2009 (08).

[9] Changchun: Times Literature and Art Publishing House, 2001: 548 (Qing) Li Yu.

[10] Chen Congzhou. Spring Moss Set, Guangzhou: Huacheng Press, 1985: 101

[11] (Japan) Valley of the needle Zhongji Zhu, Zou Hongcan translation history of western garden change, Beijing: China Building Industry Press, 1991: 267.

[12] Meng Zhaizhen. Park Yan, Beijing: China Building Industry Press, 2012: 133.

[13] He Yumin editor of clinical psychology of traditional Chinese medicine, Beijing: People's Medical Publishing House, 2010: 306.

[14] Jin Xuezhi. Chinese garden aesthetics, Beijing: China Building Industry Press, 2005: 291.

[15] Meng Xiangrong. Liu Lang Museum: Reflection and Perception of Life - On the significance of Yuan Hongdao six years of township, Journal of Yangtze University, 2006,29 (06).

[16] Richard Louv. Last Child in the Wood: Saving our Children from Nature-Deficit Disorder, North Carolina: Algonquin Books of Chapel Hill, 2008: 46. 